\title{
Runella slithyformis gen. nov., sp. nov., a Curved, Nonflexible, Pink Bacterium
}

\author{
JOHN M. LARKIN AND PATRICIA M. WILLIAMS \\ Department of Microbiology, Louisiana State University, Baton Rouge, Louisiana 70803
}

\begin{abstract}
Two strains of bacteria regarded as belonging to a new species were isolated from bodies of water near Baton Rouge, La. The cells of these strains were gram-negative, curved rods, the degree of curvature varying among cells in a single culture. A pink pigment was produced on glucose-peptone-yeast extract agar. The strains were nonmotile and nonfermentative, and the guanine-pluscytosine contents of their deoxyribonucleic acids varied from 49.3 to $49.6 \mathrm{~mol} \%$. The species cannot be assigned to any known genus, and therefore a new genus, Runella, is proposed, with $R$. slithyformis as the type species. The type strain of this species is strain $4(=$ ATCC 29530). At present, it is difficult to place the genus Runella in a family.
\end{abstract}

During examination of the bacteria that inhabit the bodies of fresh water in southern Louisiana, we repeatedly encountered bacteria that resembled those of the newly described genus Flectobacillus (2). The organisms were seen both on slides that had been suspended in water and in enrichments made by adding $0.1 \mathrm{~g}$ of peptonized milk to $100 \mathrm{ml}$ of the water sample. We were successful in isolating two strains of these organisms, and subsequent characterization studies indicated that they are physiologically quite different from flectobacilli even though they are similar morphologically. These strains represent a new species and genus of bacteria, descriptions of which are presented.

\section{MATHRIALS AND METHODS}

Bacterial strains. Two similar strains were isolated from water from the Baton Rouge, La., area by repeated streaking of water samples onto MS agar $(0.1 \%$ each of glucose, peptone, and yeast extract, plus $1.5 \%$ agar) with incubation at room temperature. One strain, designated as strain 4, was isolated from University Lake, and the other, designated as strain 6 , was isolated from Elbow Bayou. Cultures of these strains were maintained on MS agar, with transfers made at about 2 -week intervals.

Utilization of carbohydrates. The production of acid from carbohydrates by aerobic or anaerobic means was determined by the method of Hugh and Leifson (1), in which MS agar was used but with the glucose replaced by $1 \%$ of the substrate to be tested and the agar concentration lowered to $0.3 \%$. Incubation was continued for 8 weeks for cultures giving negative results.

Ability to grow on various media. The abilities of the organisms to grow on various media were investigated by making a single streak of the organisms from a fresh slant onto the surface of the medium and incubating at $25^{\circ} \mathrm{C}$ for a minimum of 3 weeks. The media tested were chocolate agar, blood agar, eosin-methylene blue agar, phenol red-mannitol-salt agar, phenyl ethyl alcohol agar, nutrient agar, nutrient agar plus 5\% sucrose, Trypticase soy agar, Trypticase soy agar plus $3 \%$ glucose, peptonized milk agar, MS agar, yeast extract-acetate-tryptone agar, McConkey agar, bismuth sulfide agar, and salmonella-shigella agar.

Additional characters. The techniques and methods used to determine the abilities of the strains to utilize sole carbon sources, to hydrolyze macromolecules, to produce specific enzymes or end products, and to determine their susceptibilities to antibiotics have been reported previously (2).

Two techniques were used to determine the guanine-plus-cytosine $(G+C)$ contents of the deoxyribonucleic acids (DNA) of the strains. One technique, used with strain 6, made use of the Marmur method (6) to purify the DNA, followed by determining the melting-point profile with a Gilford model 2400 spectrophotometer equipped with a temperature-controlled cuvette compartment (5). In the other technique, used with strain 4, DNA was partially purified by the method of Meyer and Schliefer (7), and the mole percent $\mathrm{G}+\mathrm{C}$ was determined by the absorbance ratio technique of Ulitzer (9). Measurements of cell size were obtained with a Filar micrometer. Photomicrographs were obtained with a Gillet and Seibert microscope equipped with a Nikon model AFM camera.

\section{RESULTS}

The results of the analysis of the two strains are summarized in Table 1 . The cells were curved rods, with the degree of curvature of individual cells within a culture varying from nearly straight to curved in the shape of a ring. Coils of two to three turns were rarely formed, and filaments up to $14 \mu \mathrm{m}$ in length were produced. This morphological variation prompted us to determine whether the cells were flexible or capable of gliding motility, but observations 
TABLE 1. Characteristics of two strains of Runella slithyformis ${ }^{a}$

\begin{tabular}{|c|c|c|c|c|c|}
\hline Character & Strain 4 & Strain 6 & Character & Strain 4 & Strain 6 \\
\hline Gram reaction & - & - & Indole production & - & - \\
\hline Pigmentation $\ldots \ldots \ldots$ & Pale pink & Pale pink & Methyl red test & - & - \\
\hline Fluorescence $\ldots \ldots \ldots$ & - & - & Voges-Proskauer test & - & - \\
\hline Formation of coils . . . . & Rare & Rare & $\mathbf{N O}_{3}$ reduction $\ldots \ldots$ & - & - \\
\hline Motility $\ldots \ldots \ldots \ldots$ & - & - & $\mathrm{H}_{2} \mathrm{~S}$ production $\ldots \ldots$ & - & - \\
\hline $\mathbf{M o l} \% \mathbf{G}+\mathbf{C} \ldots \ldots \ldots$ & 49.6 & 49.3 & Hydrolytic activity on: & & \\
\hline Cell size: & & & Cellulose & - & - \\
\hline Length $(\mu \mathrm{m})$ & $2.5-4.0$ & $2.0-4.5$ & Agar $\ldots \ldots \ldots \ldots$ & - & - \\
\hline Diameter $(\mu \mathrm{m})$ & $0.5-0.9$ & $0.6-0.9$ & Chitin & - & - \\
\hline Diameter of rings $(\mu \mathrm{m})$ & $2.0-3.0$ & $2.0-2.5$ & Gelatin & - & - \\
\hline Filament length $(\mu \mathrm{m})$ & Up to 12.0 & Up to 14.0 & Starch & sl+ & slt \\
\hline Acid produced aerobi- & & & $\ldots \ldots \ldots \ldots$ & NG & NG \\
\hline cally from: & & & Esculin ........... & - & - \\
\hline Pentoses & & & Tributyrin & + & + \\
\hline Arabinose & - & - & Litmus milk & No change & No change \\
\hline Ribose $\ldots \ldots \ldots$ & - & - & Utilization of sole carbon & & \\
\hline Xylose $\ldots \ldots \ldots$ & NG & NG & sources: & & \\
\hline Methyl pentose & & & Acetate & - & - \\
\hline Rhamnose & - & + & Benzoate & - & - \\
\hline Hexoses & & & Citrate . & - & - \\
\hline Fructose & - & - & Formate & - & - \\
\hline Galactose ........ & + & - & Glycerol phosphate . . & - & - \\
\hline Glucose & + & + & Methylamine $\ldots . .$. & - & - \\
\hline Mannose $\ldots \ldots \ldots$ & sl+ & NG & Propionate . . . . . . & - & - \\
\hline Sorbose $\ldots \ldots \ldots$ & - & - & Succinate $\ldots \ldots \ldots$ & - & - \\
\hline Glucosides & & & Tartrate $\ldots \ldots \ldots \ldots$ & - & - \\
\hline$\alpha$-Methyl-D-gluco- & - & - & Malonate $\ldots \ldots \ldots$ & - & - \\
\hline side $\ldots \ldots \ldots \ldots$ & - & - & Methanol .......... & - & - \\
\hline Salicin & - & - & Growth on agar media: & & \\
\hline Disaccharides & & & Chocolate & 1 & 1 \\
\hline Cellobiose & - & - & Blood ..... & NG & NG \\
\hline Lactose ... & - & - & $\ldots \ldots \ldots \ldots$ & NG & NG \\
\hline Maltose $\ldots \ldots \ldots$ & + & + & $\ldots \ldots \ldots \ldots$ & 3 & 3 \\
\hline Melibiose . . . . . . . & - & - & NAS & NG & NG \\
\hline Sucrose . & + & + & PRMS & NG & NG \\
\hline Trehalose $\ldots \ldots$ & NG & NG & $\ldots \ldots \ldots \ldots$ & NG & NG \\
\hline Trisaccharide & & & 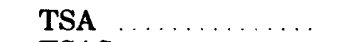 & NG & NG \\
\hline Raffinose $\ldots$ & - & + & TSAS $\ldots \ldots \ldots \ldots$ & NG & NG \\
\hline Polysaccharides & & & TSAG & NG & NG \\
\hline Dextrin . . . . . . . . & - & - & PMA & 1 & 1 \\
\hline Inulin & + & + & MS. & 4 & 4 \\
\hline Alcohols & & & YEAT & 1 & 1 \\
\hline Glycerol & - & - & McConkey & NG & NG \\
\hline Erythritol $\ldots \ldots \ldots$ & - & - & BS $\ldots \ldots$ & NG & NG \\
\hline Dulcitol & - & - & SS & NG & NG \\
\hline Mannitol & - & - & Antibiotic susceptibility & & \\
\hline Sorbitol & - & - & to: & & \\
\hline Production of enzymes & & & Actinomycin D $(100$ & & \\
\hline Urease $\ldots \ldots \ldots$ & - & - & $\mu \mathrm{g} / \mathrm{ml})$ & $\mathbf{S}$ & $\mathbf{S}$ \\
\hline Lecithinase ....... & - & - & Ampicillin $(10 \mu \mathrm{g})$ & $\mathbf{S}$ & $\mathbf{S}$ \\
\hline Lysine decarboxylase & - & - & Aureomycin $(15 \mu \mathrm{g})$ & $\mathrm{S}$ & $\mathrm{S}$ \\
\hline Ornithine decarboxyl- & - & - & Carbenicillin $(50 \mu \mathrm{g})$ & $\mathbf{S}$ & $\mathbf{S}$ \\
\hline ase $\ldots \ldots \ldots$ & - & - & Cephalothin $(30 \mu \mathrm{g})$. & $\mathbf{S}$ & $\mathbf{S}$ \\
\hline Phenylalanine deami- & - & - & Colistin $(10 \mu \mathrm{g}) \ldots$ & $\mathbf{R}$ & $\mathbf{R}$ \\
\hline nase $\ldots \ldots \ldots$ & - & - & Erythromycin $(15 \mu \mathrm{g})$ & $\mathbf{S}$ & $\mathbf{S}$ \\
\hline ONPG & + & + & Furadantin/macrodantin & $\mathbf{S}$ & $\mathbf{S}$ \\
\hline Oxidase & + & + & $(300 \mu \mathrm{g})$ & $\mathbf{s}$ & $\mathbf{S}$ \\
\hline Catalase ..... & slt & slt & Gentamycin $(10 \mu \mathrm{g})$ & $\mathbf{S}$ & $\mathbf{S}$ \\
\hline Phosphatase . & + & + & Kanamycin $(30 \mu \mathrm{g})$ & $\mathbf{R}$ & $\mathbf{S}$ \\
\hline Hemolysin .... & - & - & & & \\
\hline
\end{tabular}


TABl.E 1-Continued

\begin{tabular}{lll||ccc}
\hline \multicolumn{1}{c|}{ Character } & Strain 4 & Strain 6 & Character & Strain 4 & Strain 6 \\
\hline Mitomycin C $(1 \mu \mathrm{g} / \mathrm{ml})$ & $\mathrm{S}$ & $\mathrm{S}$ & Sulfamethoxyzole/tri- & & \\
Neomycin $(30 \mu \mathrm{g})$ & $\mathrm{S}$ & $\mathrm{R}$ & methopterin $(25$ & $\mathrm{S}$ & $\mathrm{S}$ \\
Penicillin G $(10 \mathrm{U})$ & $\mathrm{S}$ & $\mathrm{S}$ & $\mu \mathrm{g})$ & & \\
Polymyxin B $(300 \mathrm{U})$ & $\mathrm{R}$ & $\mathrm{R}$ & Tetracycline $(30 \mu \mathrm{g})$ & $\mathrm{S}$ & $\mathrm{S}$ \\
Streptomycin $(10 \mu \mathrm{g})$ & $\mathrm{S}$ & $\mathrm{S}$ & Triple sulfa $(1 \mathrm{mg})$ & $\mathrm{R}$ & $\mathrm{R}$ \\
\hline
\end{tabular}

"Symbols: + , positive, - , negative; $N G$, no growth. The growth responses on various media are graded from 1 to 4 for scant to luxurious growth, repectively. Abbreviations: S, susceptible; R, resistant; EMB, eosinmethylene blue; NA, nutrient agar; NAS, nutrient agar plus 5\% sucrose; PRMS, phenol red-mannitol-salt agar; PEA, phenyl ethyl alcohol agar; TSA, Trypticase soy agar; TSAG, Trypticase soy agar plus $3 \%$ glucose; PMA, peptonized milk agar; YEAT, yeast extract-acetate-tryptone agar; BS, bismuth sulfide agar; SS, salmonella-shigella agar.

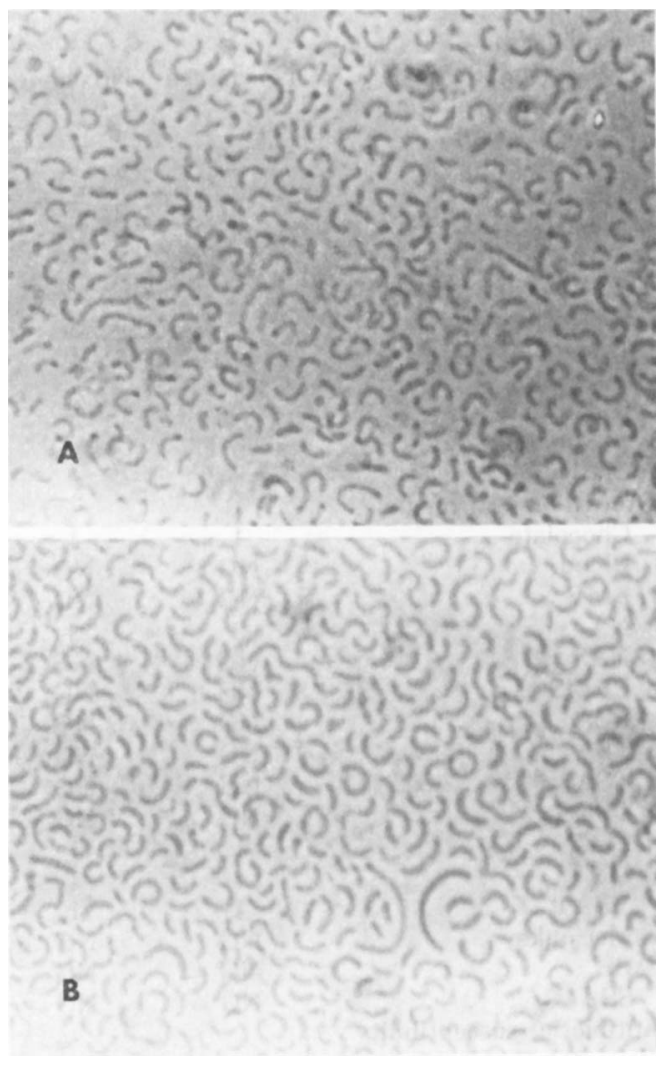

Fig. 1. Phase micrographs of cells of two strains of Runella slithyformis: (A) strain 4, and (B) strain 6. $\times 1,500$.

of the cells in microculture, in broth, and on agar media indicated that they were rigid and nonmotile.

In the Hugh and Leifson (1) oxidation/ fermentation technique, the cells grew and produced acid only aerobically, thus indicating a respiratory metabolism. Acid was produced from less than one-third of the carbohydrates tested, and some carbohydrates (xylose, trehalose) appeared to prevent growth in three replicate sets of tubes. Figure 1 shows the typical morphology of these two strains.

\section{DISCUSSION}

The organisms described above are sufficiently different from those of the known genera to merit their recognition as members of a new genus, which we propose to call Runella. In Table 2 are listed some of the characteristics that help to differentiate Runella from other genera that have some characteristics in common with the new genus.

Runella resembles Vibrio in DNA G+C content and in being curved, but it differs from Vibrio in being nonmotile, nonfermentative, incapable of anaerobic growth, and in producing a pink pigmentation. Runella differs from $\mathrm{Cy}$. tophaga and Flexibacter in DNA G+C content and in being nonmotile; additionally, it differs from Cytophaga in being nonfermentative and unable to hydrolyze cellulose, agar, or chitin. Runella differs from Spirosoma in that the former is unable to produce coiled filaments readily or to hydrolyze gelatin and in that it produces a pink pigment rather than the yellow pigment produced by Spirosoma. Moreover, Runella produces acid from much fewer carbohydrates than does Spirosoma (2), and it is unable to utilize glycerol phosphate, succinate, tartrate, or malonate as the sole source of carbon.

In its cellular morphology and pigmentation, Runella most nearly resembles Flectobacillus, but it differs from that genus in that it has a higher DNA $\mathrm{G}+\mathrm{C}$ content and is unable to produce urease, to hydrolyze esculin and gelatin, or to grow with succinate as a sole source of carbon.

These differences from the previously described genera indicate that the two isolates described in this paper should be considered as members of a new genus, Runella. The name is derived from the Middle English word 'rune,' which meant secret writing and which later became an alphabet used by ancient Scandinavians and Anglo-Saxons. The irregular curvature 
of the cells resembles some of the early runic figures.

A description of the genus follows:

Runella gen. nov. (Run. el la. M.E. n. rune an ancient alphabet; M.L. dim. ending -ella; M.L. fem.n. runella that which resembles figures of the runic alphabet).

Straight to curved rods, the degree of curvature varying among cells within a culture. The cells measure 0.5 to 0.9 by 2.0 to $4.5 \mu \mathrm{m}$. The ends of a cell may overlap, producing a ringshaped structure with an overall diameter of 2.0 to $3.0 \mu \mathrm{m}$. Filaments up to $14 \mu \mathrm{m}$ long may be produced. On rare occasions, a coil of two to three turns may be produced. Gram negative. Nonmotile. Not flexible. Resting stages are not known. Colonies on MS agar contain a pale pink, non-water-soluble pigment.

Metabolism is respiratory; acids are produced aerobically from several carbohydrates. Strictly aerobic. Chemoorganotrophic.

Urease is not produced, and gelatin and esculin are not hydrolyzed.

Isolated from fresh water.

The $\mathrm{G}+\mathrm{C}$ content of the DNA ranges from 49 to $50 \mathrm{~mol} \%$.

The type species is $R$. slithyformis.

Runella slithyformis sp. nov. (slith.y.form' is. slithy a nonsense word from Lewis Cároll's Jabberwocky for a fictional organism that is "slithy" and can "gyre and gimble"; L. n. forma shape, form; M.L. adj. slithyformis slithy in form).

Rods vary from nearly straight to crescent shaped; filaments up to $14 \mu \mathrm{m}$ may occur. Rings with an outer diameter of 2.0 to $3.0 \mu \mathrm{m}$ may also occur. The cells vary in diameter from 0.5 to $0.9 \mu \mathrm{m}$, and the usual length is 2.0 to $3.0 \mu \mathrm{m}$. Coiled filaments are rarely produced. Gram negative. Nonmotile. Nonflexible. On MS agar, a pale pink, nondiffusible, nonfluorescent pigment is produced.

Metabolism is respiratory. No growth occurs under an anaerobic seal of pyrogallol-potassium hydroxide. Acid is not produced from arabinose, ribose, xylose, fructose, sorbose, $\alpha$-methyl-D-glucoside, salicin, cellobiose, lactose, melibiose, trehalose, or dextrin. Acid is produced aerobically from glucose, maltose, sucrose, and inulin. Acid production from rhamnose, galactose, mannose, and raffinose is variable. Acids are not produced from the alcohols glycerol, erythritol, dulcitol, mannitol, and sorbitol.

Urease, lecithinase, lysine decarboxylase, ornithine decarboxylase, phenylalanine deaminase, and hemolysin are not produced. Oxidase, $\beta$-galactosidase, and phosphatase are produced. Catalase activity is weak. Indole and $\mathrm{H}_{2} \mathrm{~S}$ are not produced. The methyl red and Voges-Proskauer tests are negative, and nitrate is not reduced.

TABLE 2. Comparison of Runella with other genera having some characteristics in common with it

\begin{tabular}{|c|c|c|c|c|c|c|}
\hline \multirow[b]{2}{*}{ Characteristic } & \multicolumn{6}{|c|}{ Genus $^{n}$} \\
\hline & Vibrio & Cytophaga & $\begin{array}{l}\text { Flexi- } \\
\text { bacter }\end{array}$ & $\begin{array}{l}\text { Spiro- } \\
\text { soma }\end{array}$ & $\begin{array}{l}\text { Flecto- } \\
\text { bacillus }\end{array}$ & Runella \\
\hline Motile (by means of) $\ldots \ldots \ldots \ldots$ & $\underset{\text { (Flagella) }}{+}$ & $\stackrel{+}{+}$ & $\begin{array}{c}+ \\
\text { (Gliding) }\end{array}$ & - & - & - \\
\hline Respiratory metabolism & + & + & + & + & + & + \\
\hline Fermentative metabolism . . . . . & + & \pm & - & - & - & - \\
\hline Anaerobic growth $\ldots \ldots \ldots$ & + & $\overline{ \pm}$ & - & - & - & - \\
\hline $\mathrm{Mol} \% \mathrm{G}+\mathrm{C}$ of DNA & $40-50$ & $33-42$ & $31-43$ & $51-53$ & $39-41$ & $49-50$ \\
\hline Hydrolysis of cellulose, chitin, or & & & & & & \\
\hline agar $\ldots \ldots \ldots \ldots \ldots \ldots$ & - & + & - & - & - & - \\
\hline$\ldots \ldots \ldots \ldots$ & - & NA & NA & - & + & - \\
\hline Esculin hydrolysis $\ldots \ldots \ldots \ldots \ldots$ & NA & NA & NA & \pm & + & - \\
\hline Gelatin hydrolysis $\ldots \ldots \ldots \ldots$ & + & + or NA & NA & + & + & - \\
\hline Helical coils $\ldots \ldots \ldots \ldots$ & - & - & - & + & Rare & Rare \\
\hline Growth on: & & & & & & \\
\hline Glycerol- $\mathrm{PO}_{4}$ & NA & NA & NA & + & - & - \\
\hline Succinate & + & NA & NA & + & + & - \\
\hline ( & NA & $\mathrm{NA}$ & NA & + & - & - \\
\hline Malonate & NA & NA & NA & + & - & - \\
\hline Pigmentation & - or yellow & $\begin{array}{l}\text { Yellow, or- } \\
\text { ange, red }\end{array}$ & $\begin{array}{l}\text { Yellow, or- } \\
\text { ange, } \\
\text { red, pink }\end{array}$ & Yellow & Pink & Pink \\
\hline
\end{tabular}

a Data for Vibrio, Cytophaga, and Flexibacter are from references 3, 4, and 8; data on Spirosoma and Flectobacillus are from reference 2 . Symbols: + , positive; - , negative; NA, data not available from the source used. 
Starch and tributyrin are hydrolyzed, but cellulose, agar, chitin, gelatin, casein, and esculin are not. Litmus milk is unchanged.

Acetate, benzoate, citrate, formate, glycerol phosphate, methylamine, propionate, succinate, tartrate, malonate, and methanol cannot be utilized as sole sources of carbon.

The $\mathrm{G}+\mathrm{C}$ content of the DNA ranges from 49.3 to $49.6 \mathrm{~mol} \%$ (thermal denaturation or ratio absorbance).

Both strains have been deposited with the American Type Culture Collection (ATCC), Rockville, Md. under the accession numbers 29530 and 29531 for strains 4 and 6, respectively. Strain 4 is designated as the type strain of $R$. slithyformis. A description of this strain is given in Table 1.

At the present time, it is difficult to place the genus Runella in a family.

\section{ACKNOWLEDGMENTS}

This work was supported by a grant from the Graduate Research Council of Louisiana State University.

\section{REPRINT REQUESTS}

Address reprint requests to: Dr. John M. Larkin, Department of Microbiology, Louisiana State University, Baton Rouge, LA 70803.

\section{LITERATURE CITED}

1. Hugh, R., and E. Leifson. 1953. The taxonomic significance of fermentative versus oxidative metabolism of carbohydrates by various gram-negative bacteriя. J. Bacteriol. 66:24-26.

2. Larkin, J. M., P. M. Williams, and R. Taylor. 197; Taxonomy of the genus Microcyclus: reintroduction and emendation of the genus Spirosoma and proposal of a new genus, Flectobacillus. Int. J. Syst. Bacteriol. 27:147-156.

3. Leadbetter, E. R. 1974. Genus I. Cytophaga Winogradsky 1929, 577; Lewin 1969, 191 emend. mut. char., p. 101-105. In R. E. Buchanan and N. E. Gibbons (ed)., Bergey's manual of determinative bacteriology, 8 th ed. The Williams and Wilkins Co., Baltimore.

4. Leadbetter, E. R. 1974. Genus II. Flexibacter Soriano 1945, 92, Levin 1969, 192 emend. mut. char., p. 105-107. In R. E. Buchanan and N. E. Gibbons (ed)., Bergey's manual of determinative bacteriology, 8 th ed. The Williams and Wilkins Co., Baltimore.

5. Mandel, M., and J. Marmur. 1968. Use of ultraviolet absorbance-temperature profile for determining the guanosine plus cytosine content of DNA. Methods Enzymol. 12B: 195-206.

6. Marmur, J. 1961. A procedure for the isolation of deoxyribonucleic acid from micro-organisms. J. Mol. Biol. 3:208-218.

7. Meyer, S. A., and K. H. Schleifer. 1975. Rapid procedure for the approximate determination of the deoxyribonucleic acid base composition of micrococci, staphylococci, and other bacteria. Int. J. Syst. Bacteriol. 25:383-385.

8. Shewan, J. M., and M. Véron. 1974. Genus I. Vibrio Pacini 1854, 411, p. 340-345. In R. E. Buchanan and N. E. Gibbons (ed.), Bergey's manual of determinative bacteriology, 8th ed. The Williams and Wilkins Co., Baltimore.

9. Ulitzer, S. 1972. Rapid determination of DNA base composition by ultraviolet spectroscopy. Biochem. Biophys. Acta 272:1-11. 